adrenoreceptors as its action can readily be reversed with conventional $\beta$ blockers. Utilisation of a lipophilic domain in the area around the $\beta$ receptor may lead to exoreceptor binding, which would then localise the drug near $\beta$ adrenoreceptors. ${ }^{30}$

We conclude that inhaled salmeterol is an effective treatment for nocturnal asthma at both 50 and $100 \mu \mathrm{g}$ twice daily, and that the $50 \mu \mathrm{g}$ dose also significantly improves objective sleep quality. Comparison of the efficacies of salmeterol and theophylline in treating nocturnal asthma is an important next step in determining the optimal treatment for asthmatic patients.

We thank Glaxo Group Research Limited for financial assistance; Miss Aileen Stuart, clinical research scientist, Glaxo Group Research Limiteci, for technical help; and Dr James Palmer, director of respiratory division, Glaxo Group Research Limited, for comments on the manuscript.

I Turner-Warwick M. Epidemiology of nocturnal asthma. Am $\mathcal{F}$ Med 1988;85 (suppl lB):6-8

2 Connolly CK. Diurnal rhythms in airway obstruction. Br $f$ Dis Ches 1979;73:357-66.

3 Montplaisir J, Walsh J, Malo JL. Nocturnal asthma: features of attacks sleep and breathing patterns. Am Rev Respir Dis 1982;125:18-22.

4 Kales A, Beall GN, Bajor GF, Jacobson A, Kales JD. Sleep studies in asthmatic adults: relationship of attacks to sleep stage and time of night. f Allergy 1968;41:164-73.

5 Kales A, Kales JD, Sly RM, Scharf MB, Tjiauw-Ling Tan, Preston TA. Sleep patterns of asthmatic children: all-night electroencephalographic studies. f Allergy Clin Immunol 1970;46:300-8.

6 Douglas NJ Nocturnal asthma. O f Med 1989;71:279-89.

6 Douglas NJ. Nocturnal asthma. Qf Med 1989;71:279-89.

and aminophylline in nocturnal asthma: relation of overnight changes in and aminophylline in nocturnal asthma: relation of overnight
lung function and plasma drug levels. Thorax 1980;35:526-30.

8 Milledge JS, Morris J. A comparison of slow release salbutamol with slow release aminophylline in nocturnal asthma. F Int Med Res 1979;7(supp 1): $106-10$

9 Davies PDO, Fennerty AG, Benfield GFA, Parrish RW, Campbell IA. Twice daily slow-release theophylline versus placebo for "morning dipping" in asthma. Br f Clin Pharmacol 1984; 17:335-40.

10 Barnes PJ, Neville L, Greening AP, Timmers J, Poole GW. Single-dose slowrelease aminophylline at night prevents nocturnal asthma. Lancet 1982; 299-301.

11 Heins $M$, Kurtin L, Oellerich M, Maes R, Sybrecht GW. Nocturnal asthma: slow-release terbutaline versus slow-release theophylline therapy. Eur Respir J 1988;1:306-10

12 Stewart IC, Rhind GB, Power JT, Flenley DC, Douglas NJ. Effects of sustained release terbutaline on symptoms and sleep quality in patients with nocturnal asthma. Thorox 1987:42:797-800.

13 Rhind GB, Connaughton JJ, McFie J, Douglas NJ, Flenley DC. Sustained release choline theophyllinate in nocturnal asthma. BMY 1985;291:1605-8.

14 Ullman A, Svedmyr N. Salmeterol, a new long acting inhaled beta 2 adrenoreceptor agonist: comparison with salbutamol in adult asthmatic patients. Thorax 1988;43:674-8.

15 Catterall JR, Douglas NJ, Calverly PMA, et al. Irregular breathing and hypoxaemia during sleep in chronic stable asthma. Lancet 1982;i:301-4

16 Rechischaffen A, Kales A. Manual of standardised terminolagy, techniques and scoring system for sleep stage of human subjects. Washington DC: Public Health Service, US Government Printing Office, 1968.

17 Horn CR, Clark TJH, Cochrane GM. Inhaled therapy reduces morning dips in asthma. Lancet $1984 ; \mathrm{i}: 1143-5$.

$18 \mathrm{Coe} \mathrm{CI}, \mathrm{Barnes} \mathrm{PJ}$. Reduction of nocturnal asthma by an inhaled anticholinergic drug. Chest 1986;90:485-8.

19 Carpentiere G, Marino S, Castello F. Effects of inhaled fenoterol on the circadian rhythm of expiratory flow in allergic bronchial asthma. Chest 1983;83:211-4.

20 Morrison JF, Pearson SB, Dean HG. Parasympathetic nervous system in nocturnal asthma. $B M \mathcal{F} 1988 ; 296: 1427-9$.

21 Rall TW. Central nervous system stimulants: the methylxanthines. In: Gilman AG, Goodman LS, Rall TW, Murad F, eds. The pharmacological basis of therapeutics. New York: MacMillan, 1985:589-603.

22 Friedman RC, Bigger JT, Kornfield DS. The intern and sleep loss. $N$ Engl 7 Med 1971;285:201-3.

23 Williams HL, Lubin A, Goodnow JJ. Impaired performance with acute sleep loss. Psychological Monographs 1959;73:1-26.

24 Glenville $M$, Broughton R, Wing AM, Wilkinson RT. Effects of sleep deprivation on short duration performance measures compared to the Wilkinson auditory vigilance task. Sleep 1978;1:169-76.

25 Fitzpatrick MF, Cheshire K, Whyte KF, Deary I, Shapiro CM, Douglas NJ. Sleep quality and daytime cognitive performance in nocturnal asthma [Abstract]. Thorax 1990;45:338P.

26 Furukawa CT, Shapiro GG, Bierman CW, Kraemer MJ, Ward DJ, Pierson WE. A double-blind study comparing the effectiveness of cromolyn sodium and sustained release theophylline in childhood asthma. Pediatrics 1984;74: and sus.

27 Springer C, Goldenberg B, Ben Dov I, Godfrey S. Clinical, physiologic, and psychologic comparison of treatment by cromolyn or theophylline in psychologic comparison of treatment by cromolyn or

28 Rachelefsky GS, Wo J, Adelson J, et al. Behavior abnormalities and poor school performance due to oral theophylline use. Pediatrics 1986;78:1133-8. 29 Rappaport L, Coffman H, Guare R, Fenton T, DeGraw C, Twarog F. Effects of theophylline on behaviour and learning in children with asthma. Am $\mathcal{J} D i$ Child 1989;143:368-72.

30 Bradshaw J, Brittain RT, Coleman RA, et al. The design of salmeterol, a long acting selective beta 2 adrenoreceptor agonist [Abstract]. Br J Pharm 1987;92(suppl):590P.

(Accepted I November 1990)

\title{
"Vanishing" of vertebra in a patient with sickle cell haemoglobinopathy
}

\section{J O Ozoh, M A C Onuigbo, N Nwankwo, S O Ukabam, B C Umerah, C C Emeruwa}

\section{University of Nigeria Teaching Hospital, P M B 01280, Enugu, Nigeria J O Ozoh, FMCR, consultant radiologist \\ M A C Onuigbo, FWACP, consultant physician and nephrologist \\ $\mathrm{N}$ Nwankwo, $\mathrm{MB}$, senior registrar \\ S O Ukabam, MRCP, consultant physician and gastroenterologist B C Umerah, FRCR, professor of radiology \\ C C Emeruwa, $\mathrm{MB}$, intern}

Correspondence to: $\mathrm{Dr}$ Ozoh.

$\operatorname{Br} \operatorname{Med} \mathcal{F} 1990 ; 301: 1368-9$
Sickle cell haemoglobinopathy is common in Nigeria, affecting $2-3 \%$ of children. ${ }^{12}$ There have been extensive reviews of radiology in patients with sickle cell haemoglobinopathy in Nigeria. ${ }^{3}$ Common radiological features in the spine include osteoporosis, osteolytic foci, biconvexity of the intervertebral disc spaces, and flattening of the vertebral bodies. To our knowledge the "vanishing" of a vertebral body has not been reported before in such patients.

\section{Case report}

A 15 year old Nigerian boy presented in July 1990 with a two year history of a swelling in the lower back. $\mathrm{He}$ had had several episodes of recurring ill health consisting of fever, bone pains, and occasional jaundice. He had also felt a mass in the left upper quadrant for more than 10 years. Two years earlier he had developed a painful swelling in the lower back, which increased in size over several weeks. This was associated with constipation and total loss of power in both legs. He had received orthodox medical and traditional medical consultations and had been bedridden for three months. After admission to hospital, and treatment with oral paracetamol, pethidine injections, oral haematinics, and topical massages with methyl salicylate and other antirheumatic liniments he had gradually recovered use of both legs. There was no history of contact with a patient with tuberculosis, and he had no other features referable to tuberculosis; he had never been treated with antituberculous drugs.

On physical examination at presentation the patient was pale and mildly jaundiced with prognathism and prominent maxillary bones. His anterior abdominal wall showed numerous scarification marks. There was hepatosplenomegaly. The spine showed prominent gibbous at L3 level, with a slight tilt to the right. At this level there was a non-tender bony mass of $5 \mathrm{~cm} \times 3 \mathrm{~cm}$ in the midline. The overlying skin showed three healed pressure ulcers, the right leg was weak (power 4/5), and his gait indicated slight scoliosis to the right and a slight limp of the right foot. The result of the straight leg raising test was positive for the right leg at $60^{\circ}$. The right hamstring muscles were tender to palpation. Sensation to touch and pain was intact. There was a left lateral malleolar ulcer, which was healing with paper thin re-epithelialisation.

Laboratory investigations disclosed anaemia (haemoglobin $87 \mathrm{~g} / \mathrm{l}$ ), an erythrocyte sedimentation rate of $113 \mathrm{~mm}$ in the first hour, genotype SS, and a Mantoux test result of $10 \mathrm{~mm}$. Results of liver function tests and serum electrolyte, urea, and creatinine concentrations were normal. Chest and skull radiographs were normal except for coarse trabeculation of the ribs. Plain abdominal radiographs showed multiple faceted gall stones. Spinal radiographs showed diffusely generalised osteoporosis, trabeculation, and pencil 


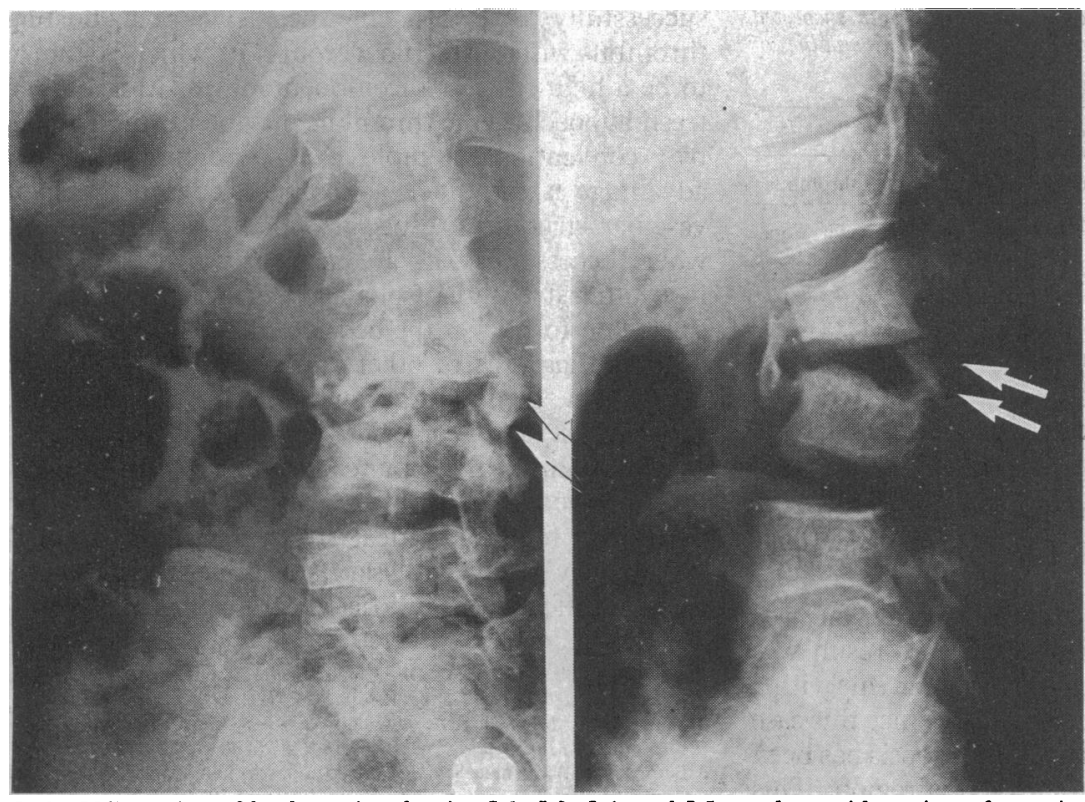

Left: Oblique view of lumbar spine showing $L 1, L 2, L 4$, and $L 5$ vertebrae with vestiges of posterio elements of $L 3$ (arrowed). Note codfish appearance of L2, L4, and LS.

Right: lateral view of lumbar spine showing narrowing of disc spaces of $T 12$ and L 1 and kyphos between L2 and L4, pseudo-Schmorl's nodes at upper and lower surfaces of T12, and bridging anterio-lateral osteophytes between L2 and L4. Only vestiges of posterior elements of L 3 body are present (arrowed)

thinning of vertebrae. There was anterior wedging of the L2; narrowing of T12-L1, L1-L2, and L5-S1 disc spaces; and codfish appearance of L2, L4, and L5. Pseudo-Schmorl's nodes were seen in T11 and both upper and lower surfaces of T12. Bridging anterolateral osteophytes were seen between L2 and L4. Most impressively, there was a complete effacement of L3, with only vestiges of the posterior elements remaining (figure).
The patient, who presented with mild painful crisis, received analgesics and antimalarial drugs and was discharged taking folic acid, multivitamins, and malarial prophylactic drugs. Surgical opinion on the gall stones favoured non-intervention as they were not causing symptoms. He was referred back to the consultant medical outpatient clinic.

\section{Comment}

To our knowledge our patient is the first patient with sickle cell haemoglobinopathy with such ubiquity and range of radiological changes. The pathology of the radiological features is based on infarction after anoxia, with or without secondary infection, giving osteomyelitis and marrow hyperplasia after recurrent haemolysis and the resulting anaemia. ${ }^{34}$ As our patient recovered from his paraplegia after receiving only analgesics, haematinics, and antirheumatic treatment and without antituberculous treatment, it is unlikely that he had had tuberculosis of the spine. The vanishing of the vertebra, spondylitis, pseudoSchmorl's nodes, and narrowed disc spaces may possibly be explained on the basis of vasco-occlusive infarction, secondary infection, compressive forces along the spine, and reactive bone responses.

1 Effiong CE. Sickle cell disease in childhood. In: Isaacs-Sodeye A, ed. Sickle cell disease. A handbook for the general clinician. Ibadan: Caxton Press (for the sickle cell club of Nigeria), 1975:16-22.

2 Henderickse RG. Sickle cell anaemia in Nigerian children. African fournal of Medicine 1960;6:45-7.

3 Lagundoye SB. Radiological features of sickle cell anaemia and related hemoglobinopathies in Nigeria. Afr f Med Med Sci 1970;1:315-42.

4 Lagundoye SB. Radiology of sickle cell disease. In: Isaacs-Sodeye A, ed. Sickle cell disease. A handbook for the general clinician. Ibadan: Caxton Press (for the sickle cell club of Nigeria), 1975:16-22.

(Accepted 27 September 1990)

\section{Colour coded duplex sonography in suspected deep vein thrombosis of the leg}

\author{
J M Schindler, M Kaiser, A Gerber, \\ A Vuilliomenet, A Popovic, O Bertel
}

\section{Medical Clinic and Institute of Radiology, \\ Triemli Hospital, CH 8063 Zürich, Switzerland \\ J M Schindler, MD, clinical assistant \\ M Kaiser, MD, clinical assistant \\ A Gerber, MD, clinical assistant \\ A Vuilliomenet, MD, consultant cardiologist \\ A Popovic, MD, consultant radiologist \\ O Bertel, MD, consultant \\ cardiologist}

\section{Correspondence and} requests for reprints to: Dr Bertel.

BrMed f 1990;301:1369-70
Clinical diagnosis of deep vein thrombosis of the leg is inaccurate. ${ }^{12}$ Venography is the most reliable method of diagnosis, but it has several disadvantages in that it is invasive, painful, and expensive; may induce phlebitis, thrombosis, and allergic reactions; and cannot be done in patients with severe heart or renal failure or in pregnant women. ${ }^{3}$ Many non-invasive diagnostic methods have therefore been developed in the past decade. Of these only duplex sonography has comparable accuracy.

We report the results of a prospective study in patients with suspected deep vein thrombosis evaluated by both colour coded Doppler sonography and venography.

\section{Patients, methods, and results}

We studied 97 inpatients and outpatients (mean (SD) age 68 (17) years) with clinically suspected deep vein thrombosis. Twelve postoperative inpatients had been given anticoagulant drugs for one to six days. The other 85 patients had started receiving intravenous heparin after admission. In all patients colour coded duplex sonography and venography were performed within 24 hours. Sonography was performed with a $5 \mathrm{MHz}$ phased array transducer. The femoral and popliteal veins were examined with the patient in a supine position. The calf veins were not investigated.

We assessed the compressibility of the vein by pressing the transducer on it in a transverse section; the phasicity of flow during deep inspiration and expiration; and whether there was an echogenic thrombus. Five patients underwent both procedures on both legs. Sonography and venography were performed and the results interpreted independently by different investigators in the cardiovascular and radiology units respectively. For sonography the diagnostic criteria for deep vein thrombosis were incompressibility of the vein, absence of flow phasicity, and presence of an echogenic thrombus. Venography was performed and interpreted according to Rabinov and Paulin. ${ }^{4}$

The table gives the results. In addition, eight patients were diagnosed as having isolated calf vein thrombosis on venography. In one of these there was absent flow phasicity in the popliteal vein, but in the remaining seven the diagnosis could not be made on sonography.

\section{Comment}

As deep vein thrombosis cannot be diagnosed accurately by clinical examination alone and venography is invasive and sometimes contraindicated a reliable non-invasive method is needed to confirm the diagnosis and indicate treatment with oral anticoagulant or even thrombolytic drugs. A recently developed technique, colour coded duplex sonography, 